\title{
KEKERASAN TERHADAP PEREMPUAN DALAM NOVEL BIDADARI HITAM KARYA T.I. THAMRIN
}

\author{
Dewi Fitriani \\ Dosen Prodi Pendidikan Bahasa Indonesia, FKIP Universitas Jabal Ghafur
}

\begin{abstract}
ABSTRAK
Penelitian ini bertujuan mendeskripsikan dan menganalisis bentuk kekerasan terhadap tokoh perempuan dalam novel Bidadari Hitam karya T.I. Thamrin. Pendekatan yang digunakan adalah pendekatan kualitatif dengan metode deskriptif analisis. Sumber data adalah novel Bidadari Hitamkarya T.I. Thamrin. Data yang dijadikan objek dalam penelitian ini adalah kata-kata, kalimat, dan dialog pada sumber data yang mendeskripsikanbentuk-bentuk kekerasan yang dialami tokoh perempuan. Teknik analisis yang digunakan adalah teknik deskriptif kualitatif. Hasil penelitian menunjukkan bahwa bentuk-bentuk kekerasan terhadap perempuan dalam novel Bidadari Hitam karya T.I.Thamrin adalah kekerasan fisik, kekerasan psikis, kekerasan seksual, dan kekerasan ekonomi. Dengan demikian, dapat disimpulkan bahwa kekerasan terhadap perempuan terjadi berulang- ulang pada korban dan keluarganya sehingga mengakibatkan penderitaan dan kesengsaraan yang berkepanjangan. Di samping itu, konflik bersenjata yang terjadi di Aceh pada tahun 1989-2001 menambah kuantitas kekerasan yang dilakukan oleh aparat keamanan (TNI/POLRI), GAM (Gerakan Aceh Merdeka), dan warga sipil. Semua kekerasan tersebut tidak dapat diterima oleh tokoh-tokoh perempuan baik secara psikis maupun batin.
\end{abstract}

Kata kunci: Kekerasan, Perempuan, Novel

VIOLENCE AGAINST WOMEN IN THE NOVEL BIDADARI HITAM

\section{BY T.I.THAMRIN}

\begin{abstract}
The aim of this study is to describe and analyze the type that related about the violence againts women character in a novel Bidadari Hitam by T.I. Thamrin. The approach used is qualitative with analysis descriptive method. The data resource is novel Bidadari Hitam by T.I. Thamrin. The object of data in this study are words, sentence, and dialog of data resource described the types of violence experienced by the women character. In this study, used the descriptive qualitative tecnique as the analysis technique. The result of this study indicate as follows types that related about the violence of the women character in the novel of Bidadari Hitam by T.I. Thamrin are physical violence, psiyhological violence, sexual violence, and economic violence. Therefore, it can be concluded that the violence againts women occurs repeatedly with victims and their families so that cause long drawn suffering and misery. Beside that, armed conflict in Aceh in 1989 until 2001 adds to the quantity of violence by security forces (TNI/POLRI), GAM (Gerakan Aceh Merdeka), and civilians. All the violence is not accepted by women character both psychological and spiritual.
\end{abstract}

Keywords : Violence, Women, Novel

\section{PENDAHULUAN}

Penelitian ini mengkaji kekerasan terhadap perempuan dalam karya sastra. Ruang lingkup dalam kajian ini adalah bentuk kekerasan terhadap perempuan dalam novel Bidadari Hitam karya T.I. Thamrin. Penelitian ini didasari oleh hal-hal sebagai berikut. Pertama, akhir-akhir ini, tindak kekerasan semakin sering terjadi dalam masyarakat terutama kekerasan terhadap perempuan. Terjadinya kekerasan terhadap perempuan pada akhirnya akan menghambat perempuan untuk terlibat dalam kehidupan sosial, ekonomi, dan pendidikan. Hal itu (Ritzer dan Douglas, 2012: 427) melukiskan situasi perempuan sebagai akibat dari hubungan kekuasaan langsung antara laki-laki dan perempuan, di mana lakilaki mempunyai kepentingan mendasar dan 
konkret untuk mengendalikan, menggunakan, menakhlukkan, dan menindas perempuan. Kedua, kajian tentang kekerasan terhadap perempuan dilakukan untuk menelusuri pelanggaran hak asasi perempuan (pelanggaran dari prinsip-prinsip fundamental hak asasi manusia internasional dan hukum internasional) dalam situasi konflik bersenjata yang tergambar dalam karya sastra, khususnya novel. Ketiga, adanya kenyataaan bahwa topik tentang kekerasan terhadap perempuan belum banyak diangkat oleh penulis-penulis Aceh (berdasarkan pengamatan penulis) terutama kekerasan terhadap perempuan yang terkandung dalam sebuah karya sastra. Keempat, penelitan ini dilakukan juga dengan alasan kekerasan terhadap perempuan bisa terjadi di mana saja. Kekerasan tersebut bisa didapat dari berbagai strata sosial dan ekonomi, seperti yang terjadi di Propinsi Aceh. Kekerasan di Provinsi tersebut yang paling parah terjadi pada tahun 1989 sampai dengan 2001 saat terjadi konflik bersenjata antara Pemerintah Republik Indonesia dengan Gerakan Aceh Merdeka (GAM). Kelima, keingintahuan penulis terhadap kekerasan terhadap perempuan melalui karya sastra yang berupa novel dengan judul Bidadari Hitam (2008) karya T.I. Thamrin. Novel Bidadari Hitam yang berlatar historis ini menceritakan tentang beberapa tokoh perempuan yang berjuang melewati hidup di tengah pasang surut konflik di Aceh. Keenam, penulis memilih novel Bidadari Hitam karya T.I Thamrin karena novel ini berisi gambaran kehidupan perempuan pada masa konflik yang diperlakukan sangat tidak manusiawi. Lebihlebih lagi sikap-sikap dan pembakuan peranperan stereotip yang mengekalkan praktek kekerasan atau paksaan yang meluas yang berlangsung sejak lama di Aceh.

\section{KAJIAN PUSTAKA}

Pasal 1 Deklarasi Penghapusan Kekerasan terhadap Perempuan memberikan pengertian tentang kekerasan terhadap perempuan sebagai tindakan berdasarkan perbedaan jenis kelamin yang berakibat atau mungkin berakibat kesengsaraan atau penderitaan perempuan secara fisik, seksual maupun psikologis, termasuk ancaman tindakan tertentu, pemaksaan atau perampasan kemerdekaan secara sewenang-wenang, baik yang terjadi di depan umum maupun dalam kehidupan pribadi. Padahal, perempuan berhak menikmati dan memperoleh perlindungan hak asasi manusia dan kebebasan asasi yang sama dengan laki-laki dalam bidang politik, ekonomi, sosial, budaya, sipil atau bidangbidang lainnya (Luhulima, 2007: 161).

Bentuk-bentukkekerasan terhadap perempuan (Harnoko, 2010: 184; Azriana, 2009; Hanita, 2009; UU No. 23 Tahun 2004; Poerwandari, 2000; Herkutanto, 2000: 268) dapat berupa kekerasan fisik, kekerasan psikis, kekerasan seksual, dan penelantaran ekonomi atau kekerasan ekonomi, dengan penjelasan sebagai berikut.

1) Kekerasan fisik

Kekerasan fisik adalah segala tindakan yang menyasar atau ditujukan untuk menyakiti tubuh atau fisik perempuan dengan anggota tubuh pelaku (tangan atau kaki) atau dengan alat-alat lain. Wujud kekerasan ini seperti memukul, menampar, menendang, mencekik, menjambak, mendorong dengan kasar, menginjak, dan sebagainya.

2) Kekerasan psikis

Kekerasan psikis adalah tindakan yang menyasar atau ditujukan untuk menyakiti psikis perempuan dan merendahkan citra seorang perempuan, baik melalui kata-kata maupun perbuatan yang menekan emosi perempuan. Wujud kekerasan ini dapat seperti bentakan, hinaan, dan ancaman.

3) Kekerasan seksual

Kekerasan seksual adalah segala tindakan yang menyasar atau ditujukan untuk menyakiti atau merusak organ-organ seksual perempuan ataupun mengarah pada penghinaan seksualitas perempuan. Kekerasan seksual bisa berupa ucapan tidak senonoh yang berkaitan dengan seks, menyentuh bagian-bagian tubuh secara seksual di luar keinginan korban, hingga memaksa melakukan hubungan seksual disertai dengan janji-janji atau paksaan.

4) Kekerasan ekonomi

Kekerasan ekonomi yaitu penelantaran ekonomi adalah segala tindakan yang ditujukan untuk membatasi, mengurangi atau mengabaikan hak-hak perempuan atas penikmatan ekonomiatau sumber ekonominya. Tindak kekerasan ekonomi dapat berupa eksploitasi ekonomi, penelantaran, pengabaian, perlakuan salah, penindasan, dan penghisapan oleh seseorang atau sekelompok orang untuk kepentingan ekonomi. 


\section{METODOLOGI}

Pendekatan yang digunakan dalam penelitian ini adalah pendekatan kualitatif. Jenis penelitiannya termasuk ke dalam jenis penelitian deskriptif kualitatif. Metode yang dipakai adalah metode deskriptif analitik. Mulanya peneliti mendeskripsikan fakta-fakta yang kemudian disusul dengan analisis (Ratna, 2004: 53).

Sumber data dalam penelitian ini adalahnovel yang berjudul Bidadari Hitam. Novel ini ditulis oleh T.I. Thamrin dengan tebal 258 halaman, diterbitkan oleh Imparsial dan AJMI pada tahun 2008. Data dalam penelitian ini berupa kata-kata, kalimat, dan dialog pada sumber data yang mendeskripsikan bentuk-bentuk kekerasan terhadap tokoh perempuan dalam novel Bidadari Hitam.

Perspektif penelitian sastra ini berfokus pada teks. Teknik pengumpulan data yang digunakan dalam penelitian ini adalah menggunakan teknik kepustakaan (library research). Data dalam penelitian ini dianalisis dengan menggunakan teknik deskriptif kualitatif.

\section{HASIL DAN PEMBAHASAN}

Dalam novel Bidadari Hitam karya T.I. Thamrin menyuguhkan kekerasan terhadap perempuan di daerah Aceh saat terjadinya konflik bersenjata antara GAM (Gerakan Aceh Merdeka) dengan NKRI (Negara Kesatuan Republik Indonesia). Konflik bersenjata tersebut disebabkan oleh kebijakan penguasa yang tak memihak rakyat. Pemerintah pusat mengirim ribuan tentara ke Provinsi Aceh yang dikenal dengan daerah Serambi Mekkah, membuat sebagian besar masyarakat sipil kecewa. Pengiriman ribuan tentara telah membuat segenap lapisan masyarakat secara pribadi maupun golongan menderita dan pertumpahan darah di daerah yang juga dikenal dengan sebutan Tanoh Rencong ini pun tak bisa dielak. Kaum perempuan yang selalu dikonotasikan sebagai makhluk yang lemah dan inferior tidak bisa berbuat banyak menghadapi kekerasan yang menimpa mereka. Mereka mengalami kekerasan berulang-ulang dan di tempat yang berbeda-beda oleh pelaku kekerasan yang berbeda-beda pula. Hal itu digambarkan oleh pengarang dengan jelas dan terperinci. Karena itu, novel ini diberi judul Bidadari Hitam yang memiliki makna tersirat bahwa tokoh perempuan (yang digambarkan pengarang lewat tokoh Inong) yang digambarkan cantik dan eksotis bagaikan bidadari namun hidupnya tidak seperti bidadari pada umumnya yang hidup dengan penuh kebahagiaan. Sebaliknya, tokoh tersebut malah, selalu mengalami kekerasan sehingga mengakibatkan penderitaan hidup yang berkepanjangan.

Dalam interaksinya dengan laki-laki, kaum perempuan sering mengalami berbagai bentuk kekerasan. Kekerasan tersebut dapat berbentuk kekerasan fisik, kekerasan psikis, kekerasan seksual, dan kekerasan ekonomi. Keempat kekerasan tersebut juga terdapat dalam novel Bidadari Hitam karya T.I. Thamrin. Dalam menyikapi kekerasan, tokoh perempuan juga memiliki cara masing-masing. Kesadaran terhadap kekerasan yang dialami membuat ada di antara mereka bereaksi dengan cara yang tak biasa dilakukan oleh perempuan pada umumnya.

Kekerasan terhadap perempuan terjadi sebagai akibat dari hubungan kekuasaan langsung antara laki-laki dan perempuan, di mana laki-laki mempunyai kepentingan mendasar dan konkret untuk mengendalikan, menggunakan, dan menindas perempuan, yakni untuk melaksanakan dominasi. Dominasi adalah setiap hubungan di mana pihak (individu atau kolektif) yang dominan berhasil membuat pihak lain (individu atau kolektif) yang disubordinasikan sebagai alat kemauannya dan menolak untuk mengakui kebebasansubjektivitaspihakyang

disubordinasikan. Atau sebaliknya, dilihat dari sudut pandang pihak yang disubordinasikan, perempuan hanyalah sebagai alat kemauan pihak yang dominan (Ritzer dan Douglas, 2004: 427). Dalam novel Bidadari Hitam, hal tersebut juga terjadi.

Kekerasan fisik yang ditemukan dialami oleh tokoh Po Kaoi, Nek Sandang, Fitriah, Zahara Beuna, Inong, Ti Timah, Nek Sada, Elit Baleno, dan Mawar. Pelaku kekerasan ini yaitu sekelompok tentara, Lettu Anton Singodimejo, Ahya, Lettu Suroso Adikarso, Radja Jinn, dan Wakil Komandan Sattis. Para korban mengalami kekerasan dalam tindak kekerasan yang bermacam-macam. Tindak kekerasan yang dialami dengan cara digosok, disundut, disetrum, diseret, dipukul, dicambuk, ditempeleng, dijambak, dihajar, ditembak, disiksa, ditangkap, dihantam, dilantak, didera, dilecut, dan disiram. Para tentara melakukan kekerasan agar memperoleh informasi. Mereka tanpa rasa belas kasihan melakukan tindak 
kekerasan tersebut, malah mereka tertawa menyaksikan penderitaan yang dialami oleh korban. Kejadian tersebut mengungkapkan bahwa para tentara yang bertugas mengayomi masyarakat tidak melakukan tugasnya dengan baik malah melakukan tindak kekerasan demi mendapatkan informasi yang mereka perlukan. Karena itu, mereka telah melanggar hak asasi manusia khususnya hak asasi perempuan.

Penelitian ini menemukan bahwa pembunuhan pun dilakukan untuk memberi ganjaran bagi yang membangkang dan pelajaran bagi warga yang lain seperti yang dialami tokoh Zahara Beuna dan Nek Sada. Pada konteks ini, pengarang memberitahukan siapapun yang berani melawan tentara walaupun hanya untuk membela diri akan mengalami kekerasan dari yang tidak fatal hingga fatal sampai-sampai nyawa menjadi taruhan atas pembelaan yang dilakukan. Hal ini sesuai dengan pendapat Shiraev dan David, (2012: 266) yang mengatakan bahwa di banyak negara, membunuh dalam konteks perang dianggap sah karena mereka yang dibidik untuk dibunuh adalah kelompok "penjahat". Padahal, negara memiliki tanggung jawab untuk melindungi segenap rakyatnya dari pelanggaran Hak Asasi Manusia.

Pengarang juga memberitahukan pada masa konflik bersenjata di Aceh, siapa pun terutama warga sipil bisa dihukum dan ditahan atas tuduhan yang tidak beralasan seperti yang dialami tokoh Elit Baleno. Sebaliknya, para serdadu yang sering melakukan kekerasan seakan-akan tak tersentuh hukum sedikit pun. Mereka bisa dengan sewenang-wenangnya menangkap dan menahan seseorang yang mereka suka dan sedikit orang yang bisa melawan tindakan tersebut. Di samping itu, para tentara yang berhasil menangkap atau membunuh korban yang diincar akan mendapat kenaikan pangkat dan gaji. Dari iming-iming yang akan diberikan itu, semakin besarlah kuantitas kekerasan yang mereka lakukan. Seperti pendapat Rohier (dalam Shiraev dan David, 2012: 263) agresi diperkuat secara positif ketika tindakan agresif memiliki nilai guna dan menaikkan performa kekerasan. Individu dalam keadaan itu bisa mendapatkan kekuasaan dan kontrol, mendapat sumber daya materiil, atau melawan provokasi. Di samping itu, kekerasan terhadap perempuan juga terjadi karena kebutuhan emosional mendalam lakilaki yang terpusat pada ketakutan akan kematian dan pada pertentangan perasaan ibu yang mengasuh mereka (Ritzer dan Douglas, 2004: 431). Hal itu tercermin pada tokoh Lettu Anton. Komandan Sattis (Satuan taktis dan strategis) ini menjadi takut bila suatu saat datang anggota GAM menyerbu markasnya dan Fitriah berani membunuh atau meracuninya. Ketakutan akan datangnya kematian membuatnya semakin sering melakukan kekerasan terhadap istrinya walaupun ia dilahirkan dari seorang wanita yaitu ibunya tetapi ketakutan akan kematian membuat hilang perikemanusiaannya.

kerasan psikis yang dilakukan dengan berbagai cara juga terdapat dalam novel ini. Tokoh yang mengalami kekerasan ini yaitu Inong, Mak Santan, Fitriah, Zahara Beuna, istri pertama Lettu Anton, Nek Sandang, Fauziah, Ti Timah dan Nek Sada. Pelaku kekerasan ini yaitu seorang prada, Lettu Suroso Adikarso, Teungku Murad, masyarakat, Lettu Anton Singodimejo, Peltu Samsir Lentera, orang tua Fauziah, Nek Sada, sekelompok tentara, Wakil Komandan Sattis, dan Letnan Dua Djamari Jambak Sikundang. Kekerasan psikis dilakukan dengan cara diancam, difitnah, dicibir, ditakuti, direndahkan, dimaki, digertak, dipaksa, dan dituduh. Pengarang berusaha mengambarkan situasi pada masa konflik bersenjata yang tidak aman dan tentram bagi sebagian besar orang dan yang ada kaitannya dengan orang yang mengalami konflik tersebut. Mereka sering bertindak kasar dan lebih mendahului nafsu dan emosinya sehingga hidup menjadi berantakan dan tak jelas arah dan tujuan.

Dalam kekerasan ini, pelakunya tidak hanya laki-laki tetapi juga perempuan dan dialami hanya pada satu orang tokoh yaitu $\mathrm{Ti}$ Timah dengan cara direndahkan yang dilakukan oleh Nek Sada. Akan tetapi, jumlahnya tidak sebanding dengan kekerasan yang dilakukan oleh laki-laki. Lak-laki sering melakukan kekerasan terhadap perempuan di samping untuk memuaskan hasrat juga untuk melakukan dominasi dan jumlahnya semakin bertambah saat terjadi konflik bersenjata.

Penelitian ini juga menemukan bahwa tokoh perempuan mengalami pemerkosaan dan pelecehan seksual sebagai wujud dari kekerasan seksual. Hal tersebut dialami oleh Fitriah, Zahara Beuna, Inong, dan Ti Timah. Mereka perempuan desa dan berusia muda. Hal ini sesuai dengan pendapat Moore dan Sinclair (dalam Sunarto, 2004: 118) yang menyatakan bahwa pemerkosaan sering dilakukan terhadap perempuan berusia muda. Selanjutnya, pelaku 
kekerasan ini adalah Lettu Anton Singodimejo, Kopral Jono, Komandan Regu Brimob, para tentara, Suroso Adikarso, pasukan elite, dan para anggota Sattis. Mereka semua berprofesi sebagai aparat negara yang memiliki kewajiban melindungi dan menjaga segenap warga negara Republik Indonesia.

Menurut pelaku yaitu tentara, perempuan makhluk yang lemah yang harus ditakhlukkan dan hanya berguna untuk memuaskan keinginan nafsu saja. Dengan memerkosa perempuan, hasrat mereka telah tersalurkan daripada pergi ke tempat pelacuran yang dapat beresiko tertularnya penyakit kelamin. Seperti perkataan Santrock (2003: 428), kaum feminis percaya bahwa laki-laki disosialisasikan untuk menjadi agresif secara seksual, percaya bahwa perempuan adalah makhluk yang inferior, dan memandang kesenangan mereka sendiri sebagai tujuan yang paling penting. Para peneliti telah menemukan karakteristik berikut ini pada pemerkosa: agresi meningkatkan perasaan berkuasa atau maskulinitas pada diri si pelaku; pemerkosa merasa marah kepada kaum perempuan secara umum; dan mereka ingin melukai korban mereka. Hal ini senada dengan pendapat Koss (dalam Santrock (2003: 429), pelecehan seksual adalah salah satu bentuk kekuasaan dan dominasi seseorang terhadap orang lain, yang dapat mengakibatkan konsekuensi psikologis yang serius bagi si korban.

Pelaku yang berprofesi sebagai tentara di Aceh merasa tertekan sehingga mengalami frustasi dan stres. Karena itu, dia melampiaskan emosi dan dendamnya kepada korban. Seperti pendapat Shiraev dan David (2012: 267), kondisi sosial, kesewenangwenangan, dan diskriminasi terhadap seseorang akan menyebabkan frustasi dan stres terusmenerus sehingga menyebabkan keluarnya jumlah hormon testosteron yang berlebihan dalam tubuh orang itu.

Dalam novel Bidadari Hitam juga menjelaskan, penyelesaian masalah dengan cara kekerasan dilakukan oleh tentara tanpa ada rasa menyesal karena dianggap sesuatu yang wajar malah menjadi norma di zona konflik. Seperti pendapat Buckley (dalam Shiraev dan David, 2012: 263) yang mengatakan di komunitas di mana kekerasan merupakan cara menyelesaikan masalah yang umum, seperti di zona konflik, orang mungkin menjadikan pola perilaku kekerasan sebagai norma.
Tentara selaku pelaku yang terdiri dari kaum pria tidak mau tahu apa akibat yang akan ditimbulkan dari kekerasan yang telah mereka lakukan terhadap korban. Di samping itu, pelaku kekerasan tidak merasa takut akan dihukum karena mereka yakin tidak akan diadili atas perbuatan yang mereka lakukan. Hal ini senada dengan pendapat Eagly (dalam Shiraev dan David, 2012: 267) faktor kemiskinan, pelecehan, kekerasan, kurangnya model peran pria, kejayaan perang dan lemahnya hukum, semuanya meningkatkan perilaku menyimpang dan destruktif pada lelaki dengan porsi yang lebih besar ketimbang pada wanita.

Kekerasan terhadap perempuan berbentuk kekerasan ekonomi dengan cara diperas, dirampas, disita, dan ditelantarkan ditemukan juga dalam penelitian ini. Korban kekerasan ini adalah Mak Santan dan Fitriah. Pelaku kekerasan ini adalah GAM, tentara pendatang, cuak (mata-mata tentara), dan Lettu Anton Singodimejo. Pengarang dengan detailnya menggambarkan kekerasan ekonomi yang menimpa para tokoh. Hal itu menyebabkan cerita yang disajikan seakanakan benar-benar terjadi di dunia nyata pada masa konflik bersenjata di daerah Aceh di tempat yang disebutkan dalam novelnya.

Korban yang berusaha membela diri atas segala tuduhan yang dilontarkan kepadanya malah disambut tentara dengan tindak kekerasan. Pengarang berusaha menampilkan dengan jelas bagaimana pembelaan atas tuduhan selalu dibalas dengan kekerasan pada masa konflik bersenjata di Aceh. Tentara bukan berusaha menyelesaikan masalah dengan musyawarah atau dengan cara baik-baik sesuai koridor hukum yang berlaku, malah sebaliknya selalu menanganinya melalui kekerasan. Kedamaian dan ketenangan sangat langka di masa konflik bersenjata ditambah dengan penindakan kejahatan kemanusian melalui jalur hukum yang tak pernah terwujud membuat perempuan Aceh semakin menderita pada masa itu. Seperti pendapat Shiraev dan David, (2012: 267) banyak kasus kekerasan tidak dibawa ke pengadilan karena sejumlah alasan.

Novel ini juga mengungkapkan kesewenang-wenangan pemerintah, yang memiliki kewajiban untuk melindungi segenap warga negara ternyata telah membiarkan terjadinya kekerasan di daerah konflik bersenjata. Sebagian besar masyarakat Aceh tidak bisa membantu, takut hal yang sama akan 
menimpa mereka. Cara aman yang mereka lakukan adalah berdiam diri, menyaksikan kekerasan psikis ada di sekeliling mereka tanpa bisa berbuat apa-apa.

Kekerasan yang menimpa tokoh-tokoh perempuan dalam novel Bidadari Hitam menjadi cerminan betapa menderitanya perempuan pada masa konflik bersenjata antara NKRI dengan GAM. Mereka menjadi korban kekerasan yang dilakukan oleh aparat keamanan (TNI/POLRI) dan GAM sedangkan pemerintah daerah mulai dari desa hingga provinsi seakan menutup mata atas kekerasan yang menimpa masyarakatnya. Perempuanperempuan desa yang kurang berpendidikan dan berada dalam garis kemiskinanlah yang harus menanggungnya. Meskipun pelanggaran hak asasi perempuan dalam situasi konflik bersenjata adalah pelanggaran dari prinsipprinsip fundamental hak asasi manusia internasional dan hukum kemanusiaan, malah tentara yang banyak menjadi pelaku kekerasan terhadap perempuan di Provinsi Aceh. Karena itu pengarang berpesan kepada pembaca untuk selalu dekat dengan Tuhan (bertakwa) agar dijauhkan dari hal-hal yang tidak baik dan melakukan hal-hal yang baik.

\section{PENUTUP}

Berdasarkan hasil penelitian dan pembahasan yang dilakukan, penulis dapat menarik kesimpulan mengenai bentuk kekerasan terhadap tokoh perempuan dalam novel Bidadari Hitam karya T.I. Thamrin bahwa bentuk-bentuk kekerasan yang dialami tokoh perempuan berupa kekerasan fisik, kekerasan psikis, kekerasan seksual, dan kekerasan ekonomi. Kekerasan terhadap tokoh perempuan yang paling banyak adalah berbentuk kekerasan psikis. Kekerasan dalam novel ini terjadi akibat kesewenang-wenangan dan dominasi yang dilakukan laki-laki terhadap perempuan. Di samping itu, konflik bersenjata yang terjadi di Aceh sekitar tahun 1989-2001 menambah kuantitas kekerasan yang dilakukan oleh aparat keamanan (TNI/POLRI) maupun GAM dan warga sipil. Hal ini menyiratkan kekerasan terjadi berulang-ulang pada korban dan keluarganyayang mengakibatkan penderitaan dan kesengsaraan yang berkepanjangan.

Berdasarkan hasil penelitian, penulis menyarankan beberapa hal berikut. Pertama, kekerasan terhadap perempuan sebaiknya diperhatikan dan dihapuskan oleh pemerintah dan segenap elemen masyarakat demi terwujudnya masyarakat yang damai khususnya di daerah Provinsi Aceh. Kedua, peneliti berharap kepada peneliti-peneliti selanjutnya agar dapat meneliti lagi tentang kekerasan terhadap perempuan dalam karya sastra yang lain. Ketiga, hasil penelitian ini diharapkan bisa menjadi acuan bagi perkembangan penelitian berikutnya yang ingin mengkaji tentang kekerasan terhadap perempuan, khususnya dalam karya sastra.

\section{DAFTAR PUSTAKA}

Azriana, dkk. 2009. Buku Pegangan Bagi Pendamping Perempuan dan Anak Korban Kekerasan: Dikomplikasi dari Materi Training Penguatan Hukum Perempuan. Banda Aceh: RpuK.

Hanita, Margaretha, dkk. 2009. Modul Pelatihan Penanganan Kekerasan terhadap Perempuan dan Anak. Jakarta: P2TP2A Provinsi DKI Jakarta.

Harnoko, B. Rudi. 2010. "Dibalik Tindak Kekerasan terhadap Perempuan". Muwazah. Vol 2, No.1 tahun 2010. http://ejournal.stainpekalongan.ac.id. Diunduh tanggal 15 Oktober 2015.

Herkutanto. 2000. "Kekerasan terhadap Perempuan dan Sistem Hukum Pidana: Pendekatan dari Sudut Pandang Kedokteran". Dalam Tapi Omas Ihromi, dkk. (Eds.). Penghapusan Diskriminasi terhadap Wanita (hlm. 263-276). Jakarta: ALUMNI.

Luhulima, Achie Sudiarti. 2007. Bahan Ajar tentang Hak Perempuan: UU No. 7 Tahun 1984 tentang Pengesahan Kovensi Mengenai Penghapusan Segala Bentuk Diskriminasi Terhadap Wanita. Jakarta: Yayasan Obor Indonesia.

Poerwandari, E. Kristi. 2000. Kekerasan terhadap Perempuan: Tinjauan Psikologi Feministik. Dalam Achie Sudiarti Luhulima (Ed.) Pemahaman Bentuk-Bentuk Tindak Kekerasan Terhadap Perempuan dan Alternatif Pemecahannya (11-50). Jakarta: ALUMNI. 
Ratna, Nyoman Kutha. 2004. Teori, Metode, dan Teknik Penelitian Sastra. Jakarta: Pustaka Pelajar.

Ritzer, George dan Douglas J. Goodman. Tanpa tahun. Teori Sosiologi Modern. Diterjemahkan oleh Alimandan. 2012. Jakarta: Ghalia Indonesia.

Sampurna, Budi. 2000. "Pembuktian dan Penatalaksanaan Kekerasan terhadap Perempuan Tinjauan Klinis dan Forensik". Dalam Achie Sudiarti Luhulima (Ed.) Pemahaman BentukBentuk Tindak Kekerasan Terhadap Perempuan dan Alternatif Pemecahannya (51-75). Jakarta: ALUMNI.

Santrock, John W. 1996. Perkembangan Remaja. Diterjemahkan oleh Shinto B. Adelar dan Sherly Saragih. 2003. Jakarta: Erlangga.

Shiraev, Eric B dan David A. Levy. Tanpa tahun. Psikologi Lintas Kultural:Pemikiran Kritis dan Terapan Modern. Diterjemahkan oleh Triwibowo. 2012. Jakarta: Kencana

Sunarto, Kamanto. 2004. Pengantar Sosiologi. Jakarta: Lembagai Penerbit Fakultas Ekonomi Universitas Indonesia.

Thamrin, T.I. 2008. Bidadari Hitam. Jakarta: Imparsial dan AJMI.

Undang-undang No. 23 Tahun 2004 tentang Penghapusan Kekerasan dalam Rumah Tangga. 